\title{
CHEMICAL PROFILE OF PLOMIN BAY SEDIMENTS
}

\author{
Višnja OREŠČANIN ${ }^{1}$, Karlo NAĐ ${ }^{2}$, Anamarija BARTOLINČIĆ ${ }^{3}$, and Vladivoj VALKOVIĆ \\ USKNI, Laboratory for Applied Nuclear Analytics ${ }^{1}$, Institute Ruđer Bošković2 Belupo $^{3}$, Zagreb, Croatia \\ Received in September 2008 \\ Accepted in March 2009
}

\begin{abstract}
Granulometric, chemical, and leaching properties of sediments dredged in the Plomin Bay (Northern Adriatic Sea, Croatia) were investigated in order to asses the risk of remobilisation of heavy metals into the water column. In total 65 samples from 65 sampling sites were taken from different sediment depths within the bay. Analysis of variance confirmed the homogeneity of granulometric and elemental composition of the investigated sediment throughout its volume. Granulometric analysis showed that all samples corresponded to a pelitic fraction $(<0.063 \mathrm{~mm})$. Bulk elemental mass fractions in the sediments were similar to literature data on relatively unpolluted areas of the Adriatic Sea. High sedimentation rate caused by constant inflow of material from the Boljunčica River drainage may be responsible for low levels of heavy metals and negligible influence of fly and bottom ash from a nearby disposal site on the chemical composition of the sediments. In contact with sea water only $0.29 \mathrm{mg} \mathrm{kg}^{-1}$ of V, $0.04 \mathrm{mg} \mathrm{kg}^{-1}$ of $\mathrm{Cr}, 0.07 \mathrm{mg} \mathrm{kg}^{-1}$ of Ni, $0.33 \mathrm{mg} \mathrm{kg}^{-1}$ of $\mathrm{Cu}, 0.67 \mathrm{mg} \mathrm{kg}^{-1}$ of $\mathrm{Zn}$ and $0.06 \mathrm{mg} \mathrm{kg}^{-1}$ of Pb could be remobilised from sediment material into the water column. However, these values increased three to ten times in case of leaching with organic acids.
\end{abstract}

KEY WORDS: dredging, heavy metals, leaching, marine sediments, organic complexes, remobilisation, sea water

The Plomin Valley, approximately $6 \mathrm{~km}$ long, is situated on the east coast of Istria, Croatia (North Adriatic), $1 \mathrm{~km}$ to the south from the town of Plomin, and $6 \mathrm{~km}$ to the northeast from a larger town of Labin. The first three $\mathrm{km}$ of the valley is dry land and the rest is below the sea level and forms the Plomin Bay. It extends in the NE-SE direction. Its outer part is surrounded by a steep slope (reaching $60^{\circ}$ to $65^{\circ}$ at places), while the inner part is marked by a gentle slope $\left(6^{\circ}\right.$ to $\left.7^{\circ}\right)$ because of the constant fluvial deposit of the Boljunčica River from its drainage area Čepić polje. For the first $600 \mathrm{~m}$ the sea is only about $1 \mathrm{~m}$ deep. The following $800 \mathrm{~m}$ sink to a depth of $20 \mathrm{~m}$ to gradually reach the deepest point of $52 \mathrm{~m}$ at the mouth of the bay. Sediment gets wider from $15 \mathrm{~m}$ to $50 \mathrm{~m}$ across this longitudinal profile.

A small settlement, Plomin Luka, started to develop at the beginning of this century and by 1932 became the most important trade harbour for central Istria. In 1932, a $4550 \mathrm{~m}$ long channel was built to drain swamps of the Čepić polje into the Plomin Bay. This channel transported not only water, but also sediments from Lake Čepić. Constant inflow of mud into the bay required constant removal to maintain this area suitable for port activity. Due to a high cost of dredging, cleaning of the bay was stopped in 1938 . Transport of the deposit was partially stopped after building the Letaj dam in 1970, that redirected the Boljunčica to flow into the Raša River, but it was too late for the Plomin Bay which was almost completely filled with mud. After the dam was built, transport of suspended matter through the channel continued, and today the estimated sedimentation rate in the bay is greater than $10 \mathrm{~cm}$ a year (1).

In 1970, Plomin 1 thermal power plant (TPP) was put in operation using local coal as fuel (2), which 
contained $10 \%$ to $15 \%$ of non-combustible matter. This non-combustible, mineral part is rich in heavy metals and radioactive materials and consists of two phases. The first is bottom ash, which settles to the bottom of the boiler together with the non-combustible part, and the second is fly ash, which is vented together with hot gases through electrostatic filters. A part of it passes through filters and is released into the atmosphere. Plomin 1 power plant used 200,000 $t$ of coal a year, and produced 30,000 t of ash, depending of the type of coal. With power plant Plomin II in operation, this figure will eventually reach $70,000 \mathrm{t}$ a year. Ash disposal site is situated in the vicinity of the power plant on the left bank of the Bišac, a stream which flows into the Plomin Bay. The composition of the bottom and fly ash depends on the type of coal used in combustion (3). Previously published data (4) for two months worth of daily measurements in coal and waste material (fly and bottom ash) from Plomin 1 power plant showed that $\mathrm{Ti}, \mathrm{V}, \mathrm{Cr}, \mathrm{Fe}, \mathrm{Ni}, \mathrm{Cu}, \mathrm{Zn}$, $\mathrm{As}, \mathrm{Se}, \mathrm{Pb}, \mathrm{Sr}, \mathrm{Y}$ and $\mathrm{U}$ were several times higher in the ash than in coal. In 1999, dredging of $610,000 \mathrm{~m}^{3}$ of mud to the depth of $6 \mathrm{~m}$ was authorised to restore activity to the Plomin Port. The mouth of the bay was designated for the dumping site.

Preliminary radiometric investigation of the Plomin Bay sediments (1) showed that the top three meters of the material were mostly flysch (95\%) eroded from the Boljunčica catchment area and deposited over the last 30 years. In other words, these three meters of sediments were deposited while the power plant was in operation.

Disposal of dredged material to the sea bottom is a common route for the transport of contaminants into the open sea $(5,6)$. Our study of the granulometric, chemical, and leaching properties of the Plomin Bay sediment was undertaken in order to assess a possible influence of the power plant on the quality of sediments as well as the risk of heavy metal remobilisation from dredged material into the water column and further penetration into the food chain.

\section{MATERIALS AND METHODS}

We took 65 samples of mud from different depths ( $1 \mathrm{~m}$ to $6 \mathrm{~m}$ ) at different sites of the bay while dredging was in progress. Each step included removal of $1 \mathrm{~m}$ of sediment by a dredger and sampling of the sediment from the created surface at $-1 \mathrm{~m},-2 \mathrm{~m}$, $-3 \mathrm{~m},-4 \mathrm{~m},-5 \mathrm{~m}$, and $-6 \mathrm{~m}$. To collect the samples we used a grab sampler and placed them in acid-washed plastic containers. Samples for chemical analysis were oven-dried at $60{ }^{\circ} \mathrm{C}$ for two days, ground, sieved, and homogenised. For granulometric analysis, approximately $300 \mathrm{~g}$ of wet sample was taken and composition determined by wet sieving (fraction $>0.045 \mathrm{~mm}$ ) and pipetting (fraction $<0.045 \mathrm{~mm}$ ). Elemental mass fractions were measured using energy dispersive X-ray fluorescence (EDXRF) (7). Measurements were carried out with a Mo anode and Mo secondary target in order to reduce background effect and to improve monochromaticity. A Siemens $\mathrm{X}$-ray apparatus, Kristallofleks 710/710H model, was used at $35 \mathrm{kV}$ and $35 \mathrm{~mA}$. Irradiation time was $2000 \mathrm{~s}$. $\mathrm{X}$-ray spectra were collected with a $\mathrm{Si}(\mathrm{Li})$ detector (FWHM $=190$ at $6.4 \mathrm{keV}$ ) and analysed using analysis of X-ray spectra by the iterative least squares fitting (AXIL) (8). IAEA standard reference material (SRM) Soil-7 and SL-1 (Lake Sediment) provided quality control for the measurements.

Following EDXRF analysis, ten grams of each dried sample was taken in order to prepare a composite sample of the dredged material. The material was mixed and homogenised and $1 \mathrm{~g}$ of the mixture was extracted by $2 \times 10^{-2} \mathrm{~mol} \mathrm{~L}^{-1}$ of citric acid, ascorbic acid, ethylenediaminetetraacetic acid (EDTA), or oxalic acid for eight hours $(9,10)$. Sediment was also extracted with sea water (solid/liquid ratio=1:10) for 24 hours. At the end of the contact time, the solid part was separated from the leachate by filtration through a white ribbon-filter paper. The extracts were diluted to $100 \mathrm{~mL}$ with double distilled water divided in two sub-samples, and adjusted to $\mathrm{pH} 3$ and $\mathrm{pH} 11$ by the addition of concentrated $\mathrm{HNO}_{3}$ or $\mathrm{NH}_{4} \mathrm{OH}$. All $\mathrm{pH}$ measurements were made with a Mettler Toledo digital $\mathrm{pH}$ meter. Following $\mathrm{pH}$ adjustment, $2 \mathrm{~mL}$ of $1 \%$ APDC was added to each flask. After 20 minutes of complexation, the suspension was filtered through a Millipore HAWP filter (pore size $0.45 \mu \mathrm{m}$; diameter $25 \mathrm{~mm}$ ) using a Millipore micro-filtration system (11). Thus prepared thin targets were air dried, protected by thin Mylar foil $(2 \mu \mathrm{m})$, and analysed with an $\mathrm{X}$-ray spectrometer. All experiments were done in triplicate.

Samples were analysed using a MiniPal4 (12) EDXFR spectrometer (PANalytical, Almelo, Nederland). X-rays were generated from an Rh tube (maximum power: $9 \mathrm{~W}$; window: $75 \mu \mathrm{m} \mathrm{Be}$; maximum high voltage: $30 \mathrm{kV}$; maximum current: $300 \mu \mathrm{A}$; cooling medium: air). In order to reduce background, filters were used between the source 
and the sample. Measurement time was $300 \mathrm{~s}$ per sample, and measurements were carried out in the air. Characteristic X-ray radiation from the sample was detected with a Si drift detector [surface: $5 \mathrm{~mm}^{2}$; FWHM for $5.9 \mathrm{keV}{ }^{55} \mathrm{Fe}: 145 \mathrm{eV}$; window: $13 \mu \mathrm{m} \mathrm{Be}$; cooling: thermo-electrical (peltier)]. The incident and emerging angles were $45^{\circ}$. Spectral data were analysed using MiniPal/MiniMate software, version 3.0. (PANalytical, Almelo, the Netherlands). In order to reduce errors due to non-homogeneous samples, a spinner system constantly rotated samples during measurement. Instrument settings were automatically checked every hour using Al-Cu alloy reference material. $\mathrm{AlK} \alpha$ and $\mathrm{CuK} \alpha$-X-ray lines from the plate were used for corrections to the energy scale, where $\mathrm{CuK} \alpha \mathrm{X}$-ray line was used for automatic gain control.

A calibration model for qualitative and quantitative analysis was created on the basis of measurements of standard solutions (Merck) in the concentration range from $10 \mu \mathrm{g} \mathrm{L}^{-1}$ to $200 \mu \mathrm{g} \mathrm{L}{ }^{-1}$, prepared and measured in the same way as unknown samples.

Statistical analysis was done using Statistica 6.0 for Windows package. The difference between sampling depths was assessed using one-way ANOVA.

\section{RESULTS AND DISCUSSION}

\section{Granulometric and chemical composition}

Table 1 shows the basic statistical parameters computed for granulometric fractions determined in sediment samples taken from six layers during the dredging of the Plomin Bay sediments. Basic statistical parameters computed for the elemental mass fractions measured in the same samples are shown in Table 2.

According to the granulometric analysis, finegrained fraction dominated in the sediment with Silt and clay constituting more than $70 \%$ of the total sediment composition. There was no significant difference in the granulometric composition between the six layers.

Chromium levels in the dredged sediments ranged from $25 \mathrm{mg} \mathrm{kg}^{-1}$ to $62 \mathrm{mg} \mathrm{kg}^{-1}$, of copper from $20 \mathrm{mg} \mathrm{kg}^{-1}$ to $44 \mathrm{mg} \mathrm{kg}^{-1}$, nickel from $20 \mathrm{mg}$ $\mathrm{kg}^{-1}$ to $40 \mathrm{mg} \mathrm{kg}^{-1}$, zinc from $69 \mathrm{mg} \mathrm{kg}^{-1}$ to $103 \mathrm{mg}$ $\mathrm{kg}^{-1}$, and lead from $7 \mathrm{mg} \mathrm{kg}^{-1}$ to $27 \mathrm{mg} \mathrm{kg}^{-1}$ (Table 2). In 1994, Giani et al. (5) reported chromium levels from $92 \mathrm{mg} \mathrm{kg}^{-1}$ to $171 \mathrm{mg} \mathrm{kg}^{-1}$ and lead levels from $15 \mathrm{mg} \mathrm{kg}^{-1}$ to $58 \mathrm{mg} \mathrm{kg}^{-1}$ for dredged Northern

Table 1 Granulometric analysis of 24 samples taken from the Plomin Bay sediment by depth

\begin{tabular}{lccccccc}
\hline Granulometric & Statistical & \multicolumn{5}{c}{ Sampling depth / m } \\
parameter & parameter / \% & $\mathbf{1}$ & $\mathbf{2}$ & $\mathbf{3}$ & $\mathbf{4}$ & $\mathbf{5}$ & $\mathbf{6}$ \\
\hline Coarse-grained & Mean & 0.9 & 0.8 & 0.4 & 0.4 & 0.6 & 0.9 \\
sand & SD & 5.9 & 0.7 & 0.3 & 0.3 & 0.7 & 1.6 \\
& Minimum & 0.1 & 0.1 & 0.1 & 0.1 & 0.1 & 0.1 \\
& Maximum & 1.4 & 1.5 & 0.6 & 0.9 & 1.1 & 5.0 \\
& Median & 0.9 & 0.9 & 0.5 & 0.3 & 0.6 & 0.1 \\
\hline Fine-grained & Mean & 27.1 & 29.2 & 25.1 & 23.8 & 29.3 & 21.2 \\
sand & SD & 7.8 & 10.8 & 4.2 & 9.0 & 9.2 & 7.4 \\
& Minimum & 16.4 & 18.1 & 20.3 & 11.6 & 22.8 & 10.9 \\
& Maximum & 37.1 & 39.3 & 27.7 & 36.1 & 35.8 & 34.1 \\
& Median & 27.9 & 29.8 & 27.4 & 23.9 & 29.3 & 21.6 \\
\hline Silt & Mean & 44.1 & 42.5 & 43.5 & 44.4 & 42.6 & 44.8 \\
& SD & 7.7 & 6.4 & 2.5 & 4.0 & 5.2 & 3.4 \\
& Minimum & 39.2 & 36.0 & 41.6 & 38.1 & 39.0 & 37.7 \\
& Maximum & 48.9 & 48.1 & 46.3 & 48.6 & 46.3 & 48.6 \\
& Median & 44.9 & 43.0 & 42.7 & 44.8 & 42.6 & 45.6 \\
\hline Clay & Mean & 27.8 & 27.4 & 30.9 & 31.4 & 27.5 & 33.1 \\
& SD & 3.2 & 5.2 & 2.2 & 5.4 & 4.7 & 4.8 \\
& Minimum & 20.3 & 22.9 & 29.1 & 25.0 & 24.1 & 27.1 \\
& Maximum & 32.4 & 33.8 & 33.3 & 40.2 & 30.8 & 43.4 \\
& Median & 28.4 & 26.5 & 30.4 & 31.3 & 27.5 & 32.7 \\
\hline
\end{tabular}


Table 2 Basic statistical parameters of elemental mass fractions measured in the Plomin Bay sediment samples taken from different depths

\begin{tabular}{|c|c|c|c|c|c|c|c|}
\hline \multirow[t]{2}{*}{ Element } & \multirow{2}{*}{$\begin{array}{c}\text { Statistical parameter / } \\
\text { mg kg }^{-1} \text { dry mass }\end{array}$} & \multicolumn{6}{|c|}{ Sampling depth / m } \\
\hline & & 1 & 2 & 3 & 4 & 5 & 6 \\
\hline \multirow[t]{5}{*}{$\mathrm{Ti}$} & Mean & 3481 & 3664 & 3377 & 3421 & 3140 & 3557 \\
\hline & SD & 221 & 577 & 463 & 421 & 264 & 519 \\
\hline & Minimum & 3248 & 3010 & 2970 & 2849 & 2970 & 2926 \\
\hline & Maximum & 3779 & 4451 & 4543 & 4388 & 3721 & 4992 \\
\hline & Median & 3448 & 3705 & 3188 & 3329 & 3090 & 3478 \\
\hline \multirow[t]{5}{*}{$\mathrm{V}$} & Mean & 106 & 88 & 96 & 97 & 98 & 100 \\
\hline & SD & 11 & 6 & 14 & 15 & 9 & 18 \\
\hline & Minimum & 100 & 82 & 79 & 81 & 87 & 71 \\
\hline & Maximum & 123 & 97 & 120 & 140 & 110 & 151 \\
\hline & Median & 101 & 89 & 96 & 96 & 96 & 99 \\
\hline \multirow[t]{5}{*}{$\mathrm{Cr}$} & Mean & 41 & 36 & 42 & 42 & 36 & 40 \\
\hline & SD & 5 & 7 & 8 & 9 & 11 & 10 \\
\hline & Minimum & 37 & 27 & 25 & 30 & 26 & 25 \\
\hline & Maximum & 47 & 43 & 52 & 56 & 50 & 62 \\
\hline & Median & 39 & 39 & 45 & 41 & 30 & 38 \\
\hline \multirow[t]{5}{*}{$\mathrm{Mn}$} & Mean & 741 & 799 & 750 & 790 & 755 & 736 \\
\hline & SD & 46 & 84 & 49 & 67 & 42 & 86 \\
\hline & Minimum & 693 & 697 & 674 & 650 & 683 & 520 \\
\hline & Maximum & 785 & 895 & 831 & 880 & 819 & 882 \\
\hline & Median & 742 & 784 & 761 & 799 & 748 & 738 \\
\hline \multirow[t]{5}{*}{$\mathrm{Ni}$} & Mean & 32 & 37 & 34 & 35 & 35 & 34 \\
\hline & SD & 3 & 2 & 4 & 4 & 1 & 5 \\
\hline & Minimum & 28 & 34 & 24 & 27 & 34 & 20 \\
\hline & Maximum & 33 & 38 & 40 & 39 & 36 & 38 \\
\hline & Median & 33 & 38 & 35 & 36 & 35 & 35 \\
\hline \multirow[t]{5}{*}{$\mathrm{Cu}$} & Mean & 30 & 33 & 33 & 35 & 34 & 32 \\
\hline & SD & 1 & 5 & 3 & 5 & 5 & 6 \\
\hline & Minimum & 28 & 29 & 27 & 28 & 26 & 20 \\
\hline & Maximum & 31 & 40 & 37 & 43 & 41 & 44 \\
\hline & Median & 31 & 32 & 33 & 35 & 34 & 31 \\
\hline \multirow[t]{5}{*}{$\mathrm{Zn}$} & Mean & 79 & 87 & 84 & 86 & 85 & 83 \\
\hline & SD & 2 & 6 & 6 & 7 & 4 & 8 \\
\hline & Minimum & 77 & 79 & 75 & 73 & 79 & 69 \\
\hline & Maximum & 82 & 96 & 94 & 96 & 90 & 103 \\
\hline & Median & 79 & 87 & 85 & 86 & 87 & 82 \\
\hline \multirow{5}{*}{$\mathrm{Pb}$} & Mean & 13 & 10 & 11 & 11 & 14 & 10 \\
\hline & $\mathrm{SD}$ & 2 & 2 & 2 & 2 & 8 & 3 \\
\hline & Minimum & 11 & 8 & 9 & 8 & 8 & 7 \\
\hline & Maximum & 15 & 13 & 17 & 15 & 27 & 16 \\
\hline & Median & 13 & 9 & 11 & 10 & 10 & 9 \\
\hline \multirow[t]{5}{*}{$\mathrm{U}$} & Mean & 4 & 3 & 4 & 4 & 4 & 5 \\
\hline & SD & 2 & 3 & 3 & 3 & 3 & 3 \\
\hline & Minimum & 3 & 0 & 0 & 0 & 0 & 0 \\
\hline & Maximum & 6 & 5 & 6 & 7 & 7 & 8 \\
\hline & Median & 3 & 5 & 5 & 5 & 5 & 5 \\
\hline
\end{tabular}


Adriatic sediments. The following values were reported by Valković and Bogdanović for the Punat Bay sediments in 1996: ND to $229 \mathrm{mg} \mathrm{kg}^{-1}$ for $\mathrm{Cr}$, $26 \mathrm{mg} \mathrm{kg}^{-1}$ to $4018 \mathrm{mg} \mathrm{kg}^{-1}$ for $\mathrm{Cu}$, ND to $89 \mathrm{mg} \mathrm{kg}^{-1}$ for $\mathrm{Ni}, 35 \mathrm{mg} \mathrm{kg}^{-1}$ to $269 \mathrm{mg} \mathrm{kg}^{-1}$ for $\mathrm{Pb}$, and $38 \mathrm{mg}$ $\mathrm{kg}^{-1}$ to $781 \mathrm{mg} \mathrm{kg}^{-1}$ for $\mathrm{Zn}$. Chromium levels reported by Paul and Meischner in 1976 (13) ranged from $18 \mathrm{mg} \mathrm{kg}^{-1}$ to $78 \mathrm{mg} \mathrm{kg}^{-1}$ and for $\mathrm{Cu}$ from $20 \mathrm{mg} \mathrm{kg}^{-1}$ to $25 \mathrm{mg} \mathrm{kg}^{-1}$. In 1978, Frignani et al. (14) reported $\mathrm{Cr}$ to range from $24 \mathrm{mg} \mathrm{kg}^{-1}$ to $66 \mathrm{mg} \mathrm{kg}^{-1}$ and from $15 \mathrm{mg} \mathrm{kg}^{-1}$ to $35 \mathrm{mg} \mathrm{kg}^{-1}$. In 1988, Bernardi et al. (15) found $31 \mathrm{mg} \mathrm{kg}^{-1}$ to $41 \mathrm{mg} \mathrm{kg}^{-1}$ of $\mathrm{Cr}, 35 \mathrm{mg} \mathrm{kg}^{-1}$ to $46 \mathrm{mg} \mathrm{kg}^{-1}$ of $\mathrm{Pb}$, and $131 \mathrm{mg} \mathrm{kg}^{-1}$ to $194 \mathrm{mg} \mathrm{kg}^{-1}$ of Zn. In 1989, Valković and Moschini (16) reported $25 \mathrm{mg} \mathrm{kg}^{-1}$ to $93 \mathrm{mg} \mathrm{kg}^{-1}$ for both $\mathrm{Cr}$ and $\mathrm{Cu}, 16$ to $129 \mathrm{mg} \mathrm{kg}^{-1}$ for $\mathrm{Pb}$, and $31 \mathrm{mg} \mathrm{kg}^{-1}$ to $163 \mathrm{mg} \mathrm{kg}^{-1}$ for $\mathrm{Zn}$ in the Punat Bay sediments. For the same locality in 1990, Legović et al. $(17,18)$ reported Cr levels to range from $26 \mathrm{mg} \mathrm{kg}^{-1}$ to $186 \mathrm{mg} \mathrm{kg}^{-1}$ and $\mathrm{Zn}$ from $25 \mathrm{mg} \mathrm{kg}^{-1}$ to $186 \mathrm{mg} \mathrm{kg}^{-1}$. Zonta et al. (19) reported the following ranges in Venice lagoon sediments in 1994: $16 \mathrm{mg} \mathrm{kg}^{-1}$ to $45 \mathrm{mg} \mathrm{kg}^{-1}$ for $\mathrm{Cr}, 18 \mathrm{mg} \mathrm{kg}^{-1}$ to $76 \mathrm{mg} \mathrm{kg}^{-1}$ for $\mathrm{Cu}, 22 \mathrm{mg} \mathrm{kg}^{-1}$ to $36 \mathrm{mg} \mathrm{kg}^{-1}$ for $\mathrm{Ni}$, $37 \mathrm{mg} \mathrm{kg}^{-1}$ to $81 \mathrm{mg} \mathrm{kg}^{-1}$ for $\mathrm{Pb}$, and $111 \mathrm{mg} \mathrm{kg}^{-1}$ to $343 \mathrm{mg} \mathrm{kg}^{-1}$ for Zn.

All these data suggest that heavy metal mass fractions measured in the Plomin Bay sediments kept within in the ranges reported for other relatively unpolluted localities of the Northern Adriatic Sea (5, 7, 13-19).

One-way ANOVA for either original or logtransformed variables (elemental mass fractions) showed no significant difference in the composition between the six layers for any of the variable tested. The difference in chemical composition between sediment samples from the first three layers (deposited at the time of power plant activity) and those deposited before this period was statistically insignificant. This means that the dredged material is homogenous in elemental composition throughout its volume.

\section{Leaching tests}

The dredged material was deposited at the sea bottom of the bay. The influence of sea water can mobilise certain elements to a significant extent (9). It is known that various naturally occurring organic complexes can highly increase the leaching potential of sea/rain water $(9,10)$. Therefore, we applied leaching procedures with the most common, naturally occurring organic acids such as EDTA, oxalic acid, and citric acid on a composite sample of dredged material to assess whether there was a risk of remobilisation of heavy metals from the mud into the water column.

Table 3 shows that sea water extraction capability ranged from $0.1 \%$ for $\mathrm{Cr}$ to $1 \%$ for $\mathrm{Cu}$, which is low. The opposite was found for oxalic acid which was the most effective among five extraction agents. $\mathrm{As} \mathrm{Cu}$, $\mathrm{Zn}$, and $\mathrm{Pb}$ have high affinity to organic complexes, these were the most susceptible to leaching by organic acids.

Under the influence of sea water, only $0.29 \mathrm{mg} \mathrm{kg}^{-1}$ of $\mathrm{V}, 0.04 \mathrm{mg} \mathrm{kg}^{-1}$ of $\mathrm{Cr}, 0.07 \mathrm{mg} \mathrm{kg}^{-1}$ of Ni, $0.33 \mathrm{mg}$ $\mathrm{kg}^{-1}$ of $\mathrm{Cu}, 0.67 \mathrm{mg} \mathrm{kg}^{-1}$ of $\mathrm{Zn}$, and $0.06 \mathrm{mg} \mathrm{kg}^{-1}$ of $\mathrm{Pb}$ could be remobilised from the sediment material into the water column. Under the worst possible leaching conditions (high load of organic matter, low $\mathrm{pH}$ value) leading to the maximum release of elements from sediment particles into the sea water, $0.78 \mathrm{mg} \mathrm{kg}^{-1}, 0.40 \mathrm{mg} \mathrm{kg}^{-1}, 0.44 \mathrm{mg} \mathrm{kg}^{-1}, 1.68 \mathrm{mg} \mathrm{kg}^{-1}$, $4.45 \mathrm{mg} \mathrm{kg}^{-1}$ and $0.46 \mathrm{mg} \mathrm{kg}^{-1}$ of the $\mathrm{V}, \mathrm{Cr}, \mathrm{Ni}, \mathrm{Cu}, \mathrm{Zn}$ and $\mathrm{Pb}$, respectively could be extracted from dredged material.

Table 3 Bulk elemental mass fractions measured in composite sample of Plomin Bay sediment and the mass fractions and percentages of elements extracted from Plomin Bay sediments by various extraction agents

\begin{tabular}{|c|c|c|c|c|c|c|c|c|c|c|c|}
\hline \multirow{3}{*}{ Element } & \multicolumn{6}{|c|}{ Mass fraction / $\mathrm{mg} \mathrm{kg}^{-1}$ dry mass } & \multicolumn{5}{|c|}{$\begin{array}{l}\text { Percentage of elements extracted from } \\
\text { sedimens with }\end{array}$} \\
\hline & \multirow[b]{2}{*}{ Total } & \multicolumn{5}{|c|}{ Extracted with } & \multirow[b]{2}{*}{$\begin{array}{c}\text { Sea } \\
\text { water }\end{array}$} & \multirow[b]{2}{*}{$\begin{array}{l}\text { Ascorbic } \\
\text { acid }\end{array}$} & \multirow[b]{2}{*}{ EDTA } & \multirow[b]{2}{*}{$\begin{array}{l}\text { Citric } \\
\text { acid }\end{array}$} & \multirow[b]{2}{*}{$\begin{array}{c}\text { Oxalic } \\
\text { acid }\end{array}$} \\
\hline & & $\begin{array}{c}\text { Sea } \\
\text { water }\end{array}$ & $\begin{array}{l}\text { Ascorbic } \\
\text { acid }\end{array}$ & EDTA & $\begin{array}{l}\text { Citric } \\
\text { acid }\end{array}$ & $\begin{array}{c}\text { Oxalic } \\
\text { acid }\end{array}$ & & & & & \\
\hline $\mathrm{V}$ & 98 & 0.29 & 0.39 & 0.10 & 0.49 & 0.78 & 0.3 & 0.4 & 0.1 & 0.5 & 0.8 \\
\hline $\mathrm{Cr}$ & 40 & 0.04 & 0.12 & 0.24 & 0.28 & 0.40 & 0.1 & 0.3 & 0.6 & 0.7 & 1.0 \\
\hline $\mathrm{Ni}$ & 34 & 0.07 & 0.14 & 0.17 & 0.37 & 0.44 & 0.2 & 0.4 & 0.5 & 1.1 & 1.3 \\
\hline $\mathrm{Cu}$ & 33 & 0.33 & 0.79 & 1.68 & 1.42 & 1.29 & 1.0 & 2.4 & 5.1 & 4.3 & 3.9 \\
\hline $\mathrm{Zn}$ & 84 & 0.67 & 1.93 & 2.86 & 3.44 & 4.45 & 0.8 & 2.3 & 3.4 & 4.1 & 5.3 \\
\hline $\mathrm{Pb}$ & 11 & 0.06 & 0.15 & 0.30 & 0.46 & 0.36 & 0.5 & 1.4 & 2.7 & 4.2 & 3.3 \\
\hline
\end{tabular}

EDTA - ethylenediaminetetraacetic acid 


\section{CONCLUSION}

Heavy metal mass fractions in sediment samples from the investigated area exhibited values lower or equal to those reported for relatively unpolluted regions of the Adriatic Sea (5, 13-19). Granulometric and chemical composition of the dredged material was highly homogeneous, exhibiting no significant difference between layers. Sediments deposited in the Plomin Bay before and during power plant activity had almost identical chemical composition.

Uniform elemental composition of samples from different layers suggests that was one prevailing source of material during the whole sedimentation period.

Contaminants introduced into the Bay by manmade sources like the power plant were highly diluted by the constant inflow of large volumes of sediment material from the Boljunčica River drainage area, which resulted in relatively low mass fractions of heavy metals.

Sea water showed low extraction capability, ranging from $0.04 \mathrm{mg} \mathrm{g}^{-1}$ to $0.67 \mathrm{mg} \mathrm{g}^{-1}$ of heavy metals. These values changed significantly in the presence of organic complexes.

Our results suggest that deposited material in the Plomin Bay poses low environmental health risk, which is in agreement with earlier findings of neither cytotoxic nor mutagenic effects of this material on bacterial test systems (20).

\section{REFERENCES}

1. Barisic D, Kniewald G, Vertacnik A, Lulic S. Preliminary results of radiometric investigations of recent sediments in the Plomin bay. In: Gereš $D$, editor. Proceedings of the $2^{\text {nd }}$ Croatian conference on waters; 19-22 May 1999; Dubrovnik, Croatia. p. 405-11.

2. Limic N, Valkovic V. The occurrence of trace elements in coal. Fuel 1986:65:1099-102.

3. Dogan O, Simek O, Nuhoglu Y, Kopya M, Ertugrul M. Xray fluorescence spectrometry analysis of trace elements in fly ash samples of Kermerkoy thermal power plants. J Trace Microprobe Techn 2001;19:289-95.

4. Valkovic V, Makjanic J, Jaksic M, Popovic S, Bos JJA, Vis DR, Wiederspahn K, Verheul H. Analysis of fly ash by X-ray emission spectroscopy and proton microbeam analysis. Fuel 1984;63:1357-62.
5. Giani M, Gabellini M, Pellegrini D, Costantini S, Beccaloni $\mathrm{E}$, Giordano R. Concentration and partitioning of $\mathrm{Hg}, \mathrm{Cr}$ and $\mathrm{Pb}$ in sediments of dredge and disposal sites of the northern Adriatic sea. Sci Total Environ 1994;158:97-112.

6. Petersen W, Willer C, Willamowski C. Remobilisation of trace elements from polluted anoxic sediments after resuspension in oxic water. Water Air Soil Pollut 1997;99:515-22.

7. Valkovic O, Bogdanovic I. PIXE and XRF analysis of marine sediments. Nucl Instrum Methods Phys Res Sect B 1996;109/110:488-92.

8. Zucchi OLAD, Dias AD, Nascimento-Filho VF, Salvador MJ. Characterization of two medicinal plants by X-ray spectrometry. J Trace Microprobe Techn 2000;18:431-9.

9. Oreščanin V, Barišić D, Mikelić L, Lovrenčić I, Rožmarić Mačefat M, Pavlović G, Lulić S. Chemical and radiological profile of the coal ash landfill in Kaštel Gomilica. Arh Hig Rada Toksikol 2006;57:9-16.

10. Erdem M, Tumen F. A study on dissolution properties of the sludges from $\mathrm{Cr}(\mathrm{VI})$ reduction-precipitation processes. J Environ Sci Health A Tox Hazard Subst Environ Eng 2004;39:253-67.

11. Orescanin V, Barisic D, Mikelic L, Lovrencic I, Rubcic M, Rozmaric-Macefat M, Lulic, S. Environmental contamination assessment of the surroundings of the ex-Sibenik's ferromanganese smelter, Croatia. J Environ Sci Health A Tox Hazard Subst Environ Eng 2004;39:2493-506.

12. Oreščanin V, Lovrenčić I, Mikelić L, Lulić S. Applicability of MiniPal 4 compact EDXRF spectrometer for soil and sediment analysis. X-ray Spectrometry 2008;37:508-11.

13. Paul J, Meischner D. Heavy metals analysis from sediments of the Adriatic sea. Senckenbergiana Marit 1976;8:91-102.

14. Frignani M, Frescari F, Quarantotto G, Poletti R. Trace heavy metals in Adriatic Sea sediments of the Italian coast from Pesaro to Po delta. Giorn Geol 1978;43:21-45.

15. Bernardi S, Costa S, Vazzoler S, Zonta R, Cecchi R, Ghermandi G. A preliminary investigation on the distribution of heavy metals in surface sediments of the Cona tidal marsh (Venice Lagoon). Il Nuovo Cimento 1988:11C:667-77.

16. Valkovic V, Moschini G. Trace-element analysis in environmental science. Nucl Instrum Methods Phys Res Sect A 1989;280:459-69.

17. Legovic $T$, Limic $N$, Valkovic V. Estimation of diffuse inputs to a coastal Sea: solution to an inverse modelling problem. Estuar Coast Shelf Sci 1990;30:619-34.

18. Legović T, Limić N, Valković V, Injuk J, Nađ M. Pollution of the Punat bay by $\mathrm{Zn}, \mathrm{Cu}$ and Pb. Fizika 1990;22(supl. 1):126-40.

19. Zonta R, Zaggia L, Argese E. Heavy metals and grain-size distribution in estuarine shallow water sediments of the Cona Marsh (Venice Lagoon, Italy). Sci Total Environ 1994;151:19-28.

20. Orescanin V, Franekic Colic J, Durgo K, Valkovic V. Investigation of mutagenic effect of metals in Plomin bay sediments by modified preincubation Ames assay. J Trace Microprobe Techn 2002;20:69-78. 


\section{Sažetak}

\section{KEMIJSKI PROFIL SEDIMENATA PLOMINSKOG ZALJEVA}

Granulometrijska i kemijska svojstva te mogućnost otpuštanja teških metala ispitivani su u sedimentima Plominskog zaljeva (Sjeverni Jadran, Hrvatska) u svrhu utvrđivanja rizika od remobilizacije teških metala iz sedimenta u stupac vode. Uzeto je 65 uzoraka s različitih točaka i dubina unutar zaljeva. Analizom varijance potvrđena je granulometrijska i kemijska homogenost cijelog volumena sedimenta, što upućuje na jedan prevladavajući izvor tijekom cijeloga sedimentacijskog razdoblja. Granulometrijskom analizom je utvrđeno da u svim uzorcima prevladava sitnozrnata frakcija $(<0,063 \mathrm{~mm})$. Koncentracije elemenata u ukupnim uzorcima sedimenata slične su literaturnim vrijednostima objavljenim za relativno onečišćena područja Jadranskog mora. Velika brzina sedimentacije uzrokovana konstantnim donosom materijala iz slijevnog područja Boljunčice vjerojatan je uzrok niskih koncentracija teških metala i slabo vidljivog utjecaja odlagališta šljake i pepela na sastav sedimenata. U kontaktu s morskom vodom moguća je remobilizacija samo 0,29 mg kg-1 V, 0,04 mg kg-1 Cr, 0,07 mg kg-1 Ni, 0,33 mg kg-1 Cu, 0,67 mg kg-1 Zn i $0,06 \mathrm{mg} \mathrm{kg}^{-1} \mathrm{~Pb}$ iz sedimenta u stupac morske vode. Ipak ove vrijednosti su tri do deset puta povećane u slučaju izluživanja s pomoću organskih kiselina.

KLJUČNE RIJEČI: izluživanje, morska voda, morski sedimenti, organski kompleksi, remobilizacija, teški metali, uklanjanje

\section{CORRESPONDING AUTHOR:}

Višnja Oreščanin

USKNI (Udruga servisera i korisnika nuklearne instrumentacije)

Laboratory for Applied Nuclear Analytics

A. Jakšića 30, 10000 Zagreb, Croatia

E-mail:vorescan@gmail.com 